\title{
20. VARYING SOURCES FOR THE LIPIDS AND HUMIC SUBSTANCES AT SITE 391, BLAKE-BAHAMA BASIN, DSDP LEG $44^{1}$
}

\author{
Daniel H. Stuermer and Bernd R.T. Simoneit, Institute of Geophysics and Planetary Physics, \\ University of California, Los Angeles, California
}

\begin{abstract}
The distribution of lipids and the stable carbon isotopes of humic substances were examined in a core from the Blake-Bahama Basin (Leg 44, Site 391) to recognize terrestrial as opposed to marine origins for these fractions. The lipids in all core sections are mainly of autochthonous marine origin with some having an allochthonous terrestrial contribution. The humic acids in the Quaternary and Miocene sediments are also mainly marine but those of Albian to Tithonian age are predominantly terrestrial. Preferential degradation of lipids compared to humic acids during transport and sedimentation of terrestrial organic matter may have occurred. The lipids examined from dark Albian sediments show similar distributions to other Cretaceous black shales, although lipid yields are much lower.
\end{abstract}

\section{INTRODUCTION}

Probably the oldest sediments existing in any oceanic basin today are present in the Blake-Bahama Basin. We have analyzed eight representative samples from this site down to a depth of 1392 meters (in the Tithonian) for lipids and humic substances in relation to depth of burial. The relative contributions of autochthonous marine and allochthonous terrigenous lipids were evaluated from the distribution data of the $n$-alkanes and $n$-fatty acids and the origin of the humic substances were differentiated using the ratios of the stable carbon isotopes. The relative amounts of humic acids versus total organic carbon were correlated to test whether the diagenetic transformation of humic substances to kerogen occurred in this core. We also analyzed the organic matter in the dark-colored Albian claystone as we were particularly interested in whether its origin was similar to the Cretaceous black shales from the southern and eastern Atlantic Ocean.

\section{EXPERIMENTAL PROCEDURES}

The samples examined were collected on board D/V Glomar Challenger, placed in glass jars, and maintained in a frozen condition until they were analyzed. All samples were from Site 391 located in the center of the Blake-Bahama Basin $\left(28^{\circ} 13.17^{\prime} \mathrm{N} ; 75^{\circ} 36.88^{\prime} \mathrm{W}\right)$ at a water depth of 4963 meters (Site 391 Report, this volume). The sample descriptions are given in Table 1 .

The frozen core samples were lyophilized, pulverized, and then extracted for 72 hours in a Soxhlet apparatus with toluene:methanol (1:1). The extracts were concentrated to near dryness and then saponified by reflux in $0.5 \mathrm{~N} \mathrm{KOH}$ in 95 per cent methanol, 5 per cent

\footnotetext{
${ }^{1}$ Contribution No. 1662: Institute of Geophysics and Planetary Physics, University of California, Los Angeles, California.
}

water for 2 hours. The non-saponifiable lipids were recovered by liquid-liquid extraction of the diluted $\left(\mathrm{H}_{2} \mathrm{O}\right)$ and acidified mixture with dichloromethane. These lipid extracts were then methylated with 14 percent $\mathrm{BF}_{3}$ in methanol and subjected to silica gel thinlayer chromatography (TLC) using dichloromethane as eluent. After development in iodine vapor, the bands corresponding to hydrocarbons, esters and ketones were scraped off the TLC plate and eluted with $\mathrm{CH}_{2} \mathrm{Cl}_{2}$. These fractions were analyzed by gas chromatography.

The gas chromatography analyses were carried out on a Hewlett-Packard Model 5830A gas chromatograph with a $16 \mathrm{~m} \times 0.75 \mathrm{~mm}$ stainless steel SCOT column coated with OV-101, programmed from 110 to $280^{\circ} \mathrm{C}$ at $4^{\circ} \mathrm{C} / \mathrm{min}$ and using $\mathrm{He}$ carrier gas $(3$ $\mathrm{m} \ell / \mathrm{min})$.

Humic acids were extracted from the sediment following the extraction of lipids described above. The dried sediment was acidified to remove carbonates and extracted in batches by shaking with $0.1 \mathrm{~N} \mathrm{NaOH}$ under nitrogen until the extracts were colorless. The basic extracts were centrifuged $(17,000 \mathrm{G} ; 45 \mathrm{~min})$ to remove suspended sediment and then acidified with $\mathrm{HCl}$ to $p \mathrm{H} 1$ to precipitate humic acid. The humic acid was washed with $0.01 N \mathrm{HCl}$ to remove salt and lyophilized to yield the dry humic acid in the protonated form.

Stable carbon isotope analyses were carried out according to methods described previously (Kaplan et al., 1970) and values are reported in the standard $\delta$ notation relative to the Chicago Pee Dee Belemnite standard.

\section{RESULTS AND DISCUSSION}

\section{Lipids}

The sample descriptions, carbon analyses, lipid yields, and data for the humic substances are given in 
TABLE 1

Sample Descriptions, Carbon Analyses, Carbon Isotope Ratios, and Lipid Yields, Site 391, Leg 44

\begin{tabular}{|c|c|c|c|c|c|c|c|c|c|c|c|c|c|}
\hline $\begin{array}{c}\text { Sample } \\
\text { (Interval in } \mathrm{cm} \text { ) }\end{array}$ & $\begin{array}{l}\text { Depth Below } \\
\text { Sea Bed }(m)\end{array}$ & Lithology & Geologic Age & $\begin{array}{c}\text { Total } C^{a} \\
(\%)\end{array}$ & $\begin{array}{c}\text { Organic } C^{a} \\
(\%)\end{array}$ & $\begin{array}{c}\mathrm{CaCO}_{3}{ }^{\mathrm{a}} \\
(\%)\end{array}$ & $\underset{(\%)}{\mathrm{HAC}^{\mathrm{b}}}$ & $\begin{array}{c}{ }^{{ }^{13}} \mathrm{CHA}^{\mathrm{c}} \\
(\% \mathrm{Oo})\end{array}$ & $\begin{array}{r}\mathrm{n} \text {-alk } \\
(\mu \mathrm{g} / \mathrm{g})\end{array}$ & $\begin{array}{l}\text { nes } \\
\text { CPI }\end{array}$ & $\mathrm{Pr} / \mathrm{Ph}$ & $\begin{array}{l}\mathrm{n} \text {-fatty } \\
(\mu \mathrm{g} / \mathrm{g})\end{array}$ & CPI \\
\hline $\begin{array}{l}391 \mathrm{~B}-1-2 \\
6-13\end{array}$ & 1.8 & $\begin{array}{l}\text { Silty clay } \\
\text { w/foram. ooze }\end{array}$ & Quaternary & 2.0 & 0.3 & 14 & 12.5 & -22.13 & 0.4 & 1.5 & 1.2 & 0.4 & 6.1 \\
\hline $\begin{array}{l}391 \mathrm{~A}-3-4, \\
22-40\end{array}$ & 150.3 & $\begin{array}{l}\text { Calcareous } \\
\text { silt and clay }\end{array}$ & Miocene & 9.0 & 0.2 & 73 & N.R. & -. & 0.1 & 2.3 & 0.5 & 0.1 & 6.3 \\
\hline $\begin{array}{l}391 \mathrm{~A}-11-0, \\
33-41\end{array}$ & 411.8 & $\begin{array}{l}\text { Marly chalk } \\
\text { w/clay clasts }\end{array}$ & Miocene & 11.2 & 0.1 & 93 & 14.3 & -20.13 & 0.2 & 1.9 & 0.9 & 0.2 & 5.9 \\
\hline $\begin{array}{l}391 \mathrm{~A}-21-4, \\
130-138\end{array}$ & 654.8 & $\begin{array}{l}\text { Dark brown } \\
\text { variegated } \\
\text { claystone }\end{array}$ & $\begin{array}{c}\text { Albian- } \\
\text { Lower Cret. }\end{array}$ & 0.4 & 0.2 & 2 & 0.85 & -27.22 & 0.4 & 1.4 & 0.4 & 0.04 & 3.6 \\
\hline $\begin{array}{l}391 C-7-2, \\
142-150\end{array}$ & 727.9 & $\begin{array}{l}\text { Dark gray } \\
\text { claystone }\end{array}$ & $\begin{array}{c}\text { Albian- } \\
\text { Lower Cret. }\end{array}$ & 1.4 & 1.2 & 1 & 1.20 & -25.44 & 0.3 & 1.6 & 0.9 & 0.07 & 9.2 \\
\hline $\begin{array}{l}391 C-14-3, \\
142-150\end{array}$ & 1004.9 & $\begin{array}{l}\text { Limestone } \\
\text { w/shale and } \\
\text { claystone }\end{array}$ & $\begin{array}{l}\text { Barremian } \\
\text { Lower Cret. }\end{array}$ & 10.5 & 0.3 & 85 & 0.04 & -27.26 & 0.4 & 1.4 & 1.4 & 0.05 & 5.4 \\
\hline $\begin{array}{l}391 \mathrm{C}-21-3, \\
138-146\end{array}$ & 1090.4 & $\begin{array}{l}\text { Calcareous } \\
\text { claystone }\end{array}$ & $\begin{array}{c}\text { Barremian- } \\
\text { Berriasian } \\
\text { (Lower Cret.) }\end{array}$ & 5.3 & 3.4 & 16 & N.R. & - & 0.5 & 1.2 & 0.7 & 0.1 & 4.5 \\
\hline $\begin{array}{l}391 C-52-2, \\
3-10\end{array}$ & 1391.6 & $\begin{array}{l}\text { Dark reddish } \\
\text { brown clay- } \\
\text { stone }\end{array}$ & $\begin{array}{c}\text { Tithonian } \\
\text { (Upper Juras.) }\end{array}$ & 3.1 & 0.4 & 22 & 0.15 & -28.08 & 0.8 & 1.7 & 1.2 & 0.7 & 2.4 \\
\hline
\end{tabular}

a Data supplied by G. Bode, Deep-Sea Drilling Project, Scripps Institution of Oceanography, University of California, San Diego.

b\% humic acid carbon relative to total organic carbon.

${ }^{\mathrm{C}}$ Versus Chicago PDB;

$\mathrm{N} . \mathrm{R} .=$ none recovered.

Table 1. The distribution diagrams for all the $n$-alkane and $n$-fatty acid fractions are shown in Figures 1 and 2.

Lipid yields from all of the samples were low, which was expected for the samples with high carbonate content and low amounts of organic carbon. The Quaternary sample, 391B-1-2, 6-13 cm, which consists of silty clay and foraminifer ooze, exhibits $n$-alkane and $n$-fatty acid distributions reflecting both a terrigenous and marine contribution. The $n$-alkanes have maxima at $n-\mathrm{C}_{29}$ (strong odd-to-even predominance in that region) and at about $n-\mathrm{C}_{17}$ (no predominance) and the $n$-fatty acids have maxima at $n-\mathrm{C}_{16}$ and mainly at $n-\mathrm{C}_{24}$ $(\mathrm{CPI}=6)$. The higher molecular weight maxima for both homologous series are typical of higher plant waxes (Simoneit, 1975, in press) and the lower molecular weight homologs, coupled with an unresolvable hydrocarbon hump maximizing at $n-\mathrm{C}_{22}$, are indicative of autochthonous marine lipids (Simoneit, 1975).

The two Miocene samples (391A-3-4, 32-40 cm, and $391 \mathrm{~A}-11-0,33-41 \mathrm{~cm}$ ) consist mainly of carbonate with minor amounts of clay. The distribution of the $n$ alkanes shows a strong predominance of $n-\mathrm{C}_{17}$ and a secondary maximum at $n-\mathrm{C}_{22}$ to $n-\mathrm{C}_{23}$ for both samples. The deeper sample also has a minor amount of higher weight $n$-alkanes. The $n$-fatty acids have bimodal distributions with maxima at $n-\mathrm{C}_{16}$ and $n-\mathrm{C}_{26}$ for both samples. The lipid composition of the upper sample, combined with the branched/cyclic hydrocarbon hump maximizing at $\mathrm{C}_{22}$, suggests an autochthonous source. The large amount of $n-\mathrm{C}_{26}$ acid may represent a possible marine lipid similar to the $\mathrm{C}_{22: 6}$ fatty acid reported for some algae (Lee and Loeblich, 1971). The origin of the lipids in the lower sample is both autochthonous marine and to a lesser extent allochthonous terrigenous. This is analogous to lipids and their origin in other carbonate sediments that have been examined previously (e.g., Simoneit, 1977a).

The two Albian samples (391A-21-4, 130-138 cm, and $391 \mathrm{C}-7-2,142-150 \mathrm{~cm}$ ) consist primarily of claystone with very low amounts of carbonate. The $n$ alkane distributions have a predominance of $n-\mathrm{C}_{17}$, a maximum at $n-\mathrm{C}_{22}$, and minor predominances of the odd-carbon-numbered alkanes to $n$ - $\mathrm{C}_{33}$. The $n$-fatty acids show a major maximum at $n-\mathrm{C}_{16}$ with a minor maximum at $\mathrm{C}_{24}$ to $\mathrm{C}_{28}$ (even predominance). We interpret these lipid distributions to represent primarily marine authochthonous material with a very minor influx of allochthonous terrigenous constituents. Both samples also have a branched/cyclic hydrocarbon hump characteristic of microbiotic residues (Simoneit, 1975).

Sample 391C-14-3, 142-150 cm, of Barremian age, consists predominantly of limestone with shale and claystone. The $n$-alkanes exhibited a predominance of $n-\mathrm{C}_{17}$ and a maximum at $n-\mathrm{C}_{22}$, with minor predominances of odd alkanes to $n$ - $\mathrm{C}_{33}$. A branched/cyclic hydrocarbon hump maximizing at $\mathrm{C}_{23}$ was also present. The $n$-fatty acids have a maximum at $n$ - $\mathrm{C}_{16}$ with minor amounts of even homologs to $n-\mathrm{C}_{30}$. The origin of these lipids is the same as reported for the previous Albian samples.

Sample 391C-21-3, 138-146 cm, of Barremian-Berriasian age, consists of calcareous claystone with a high organic carbon content (3.4\%). The $n$-alkanes show a concentration maximum at $n-\mathrm{C}_{18}$ with minor predominances of odd alkanes to $n$ - $\mathrm{C}_{33}$. The $n$-fatty acids exhibit a bimodal distribution with maxima at $n$ $\mathrm{C}_{16}$ and $n-\mathrm{C}_{28}$ (even carbon number predominance). A broad branched/cyclic hydrocarbon hump is present, indicating a petroliferous contribution to the lipids. The distributions of the normal constituents suggest that these lipids are predominantly of marine origin with some allochthonous contribution.

Sample 391C-52-2, 3-10 cm, of Tithonian age, consists of red calcareous claystone. The $n$-alkanes have a trimodal distribution, with maxima at $n-\mathrm{C}_{17}, n-\mathrm{C}_{23}$, and $n-\mathrm{C}_{31}$. A branched/cyclic hydrocarbon hump maximizing at $\mathrm{C}_{23}$ is also present. The $n$-fatty acids have 

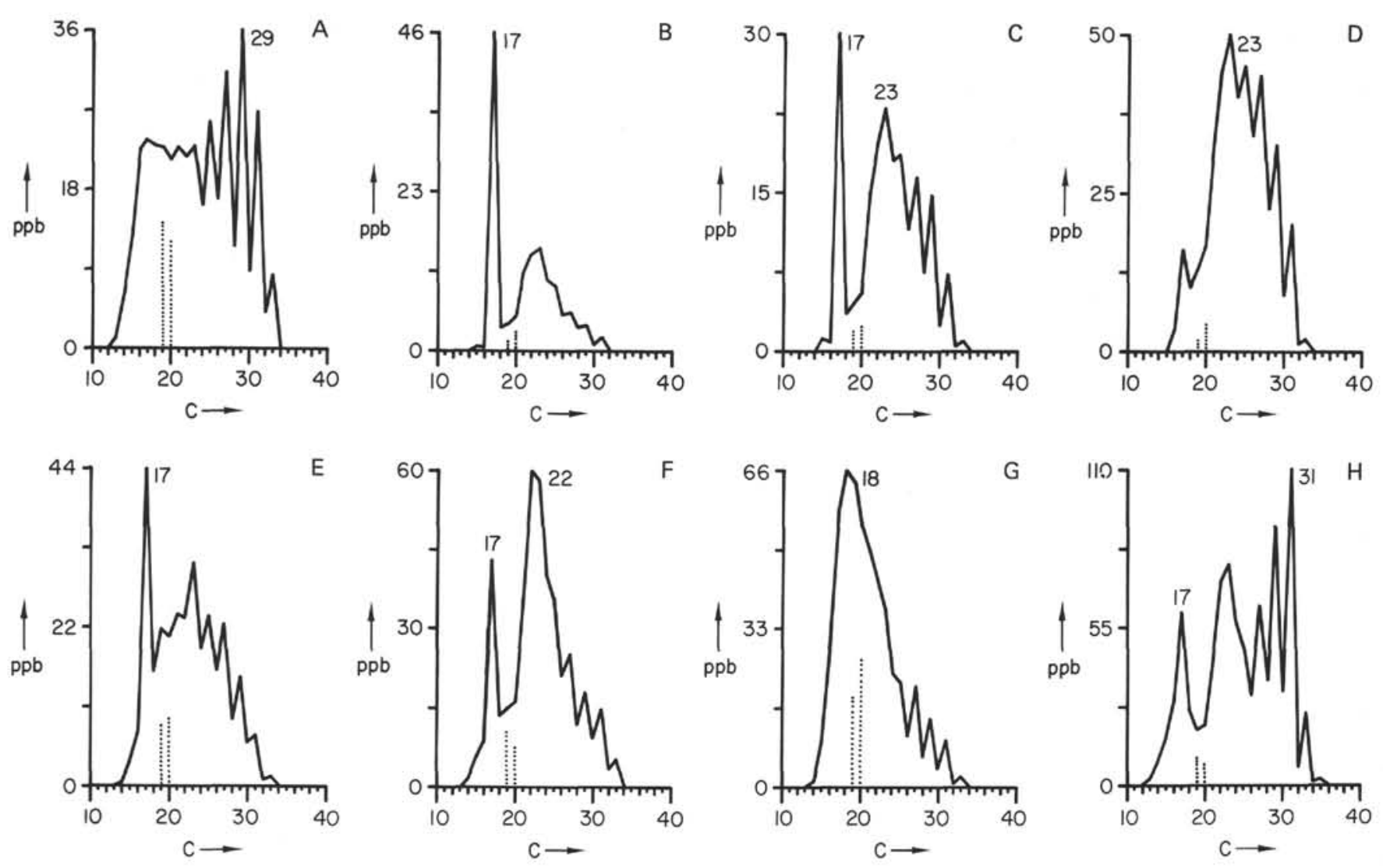

Figure 1. Distribution diagrams for the $\mathrm{n}$-alkanes (……... isoprenoids): (A) $391 \mathrm{~B}-1-2,6-13 \mathrm{~cm}$; (B) $391 \mathrm{~A}-3-4,32-40 \mathrm{~cm}$; (C) 391A-11-0, 33-41 cm; (D) 391A-21-4, 130-138 cm; (E) 391C-7-2, 142-150 cm; (F) 391C-14-3, 142-150 cm; (G) 391C-21-3, $138-146 \mathrm{~cm} ;(H) 391 \mathrm{C}-52-2,3-10 \mathrm{~cm}$.

a bimodal distribution, with maxima at $n-\mathrm{C}_{16}$ and $n-\mathrm{C}_{30}$. The origin of these lipids is both autochthonous marine and allochthonous terrigenous. The maxima at $n$ hentriacontane and at $n$-triacontanoic acid are rare for higher plant waxes and may reflect a different homologous distribution of waxes of Jurassic flora.

The approximate concentrations of phytane and pristane are indicated on the distribution diagrams (cf. Figure 1), and their ratios are given in Table 1. Pristane/phytane ratios of less than one may be indicative of anoxic environments (Didyk et al., in press). Phytanic or pristanic acids were not detected.

The branched/cyclic hydrocarbon hump maximizing at $\mathrm{C}_{22}$ to $\mathrm{C}_{23}$, coupled with a low predominance of $n$ heptadecane and an $n$-alkane maximum at $n$ - $\mathrm{C}_{22}$ or $n$ $\mathrm{C}_{23}$ (no carbon number predominance) appears to indicate a biodegraded residue of algae and other microbiota (e.g., Sample 391A-21-4, 130-138 cm). An increasing predominance of $n-\mathrm{C}_{17}$ alkane with the same humps described above appears to be a less biodegraded residue (e.g., Sample 391A-3-4, 32-40 cm).

\section{Humates}

A 100 -fold decrease with depth in the HAC/TOC ratio occurs (cf. Figure 4) from 1.8 meters to 1391.6 meters (Table 1). This indicates that either relatively less humic acid was buried during the Cretaceous and Jurassic or that humic acid was converted to kerogen after burial. Humic acid concentrations in the deeper core sections that we examined are substantially less than those reported for Recent sediments, where humic substances constitute between 10 per cent and 80 per cent of the organic matter (Bordovsky, 1965; Degens et al., 1964; Nissenbaum and Kaplan, 1972; Wakesman, 1933; Rashid and King, 1971). When Recent sediments from Tanner Basin were heated for varying times and at various temperatures, the data showed that humic acid may be converted to kerogen during early diagenesis (Ishiwatari et al., 1977). Furthermore, lithified sediments contain predominantly kerogen, with only minor amounts or no humic substances present. Although it seems clear that humic substances are converted to kerogen during diagenesis, at what stage this occurs is not known. The results presented here indicate that burial depths of greater than 500 meters and time spans in excess of 100 million years may be required.

A plot for the $\delta^{13} \mathrm{C}$ values of the humic acids versus sediment depths is shown in Figure 5. The two samples from 1.8 meters and 411.8 meters depth show $\delta^{13} \mathrm{C}$ values of $-22.13 \%$ and $-20.13 \%$, respectively, while samples from 654.8 meters and deeper have more negative values $\left(-25.44^{\circ} / 00\right.$ to $\left.-28.08^{\circ} \% 0\right)$. Nissenbaum and Kaplan (1972) have shown that $\delta^{13} \mathrm{C}$ can be used to distinguish marine from terrestrial sources of humic substances. Values between $-25 \%$ to $-29 \%$ indicate 

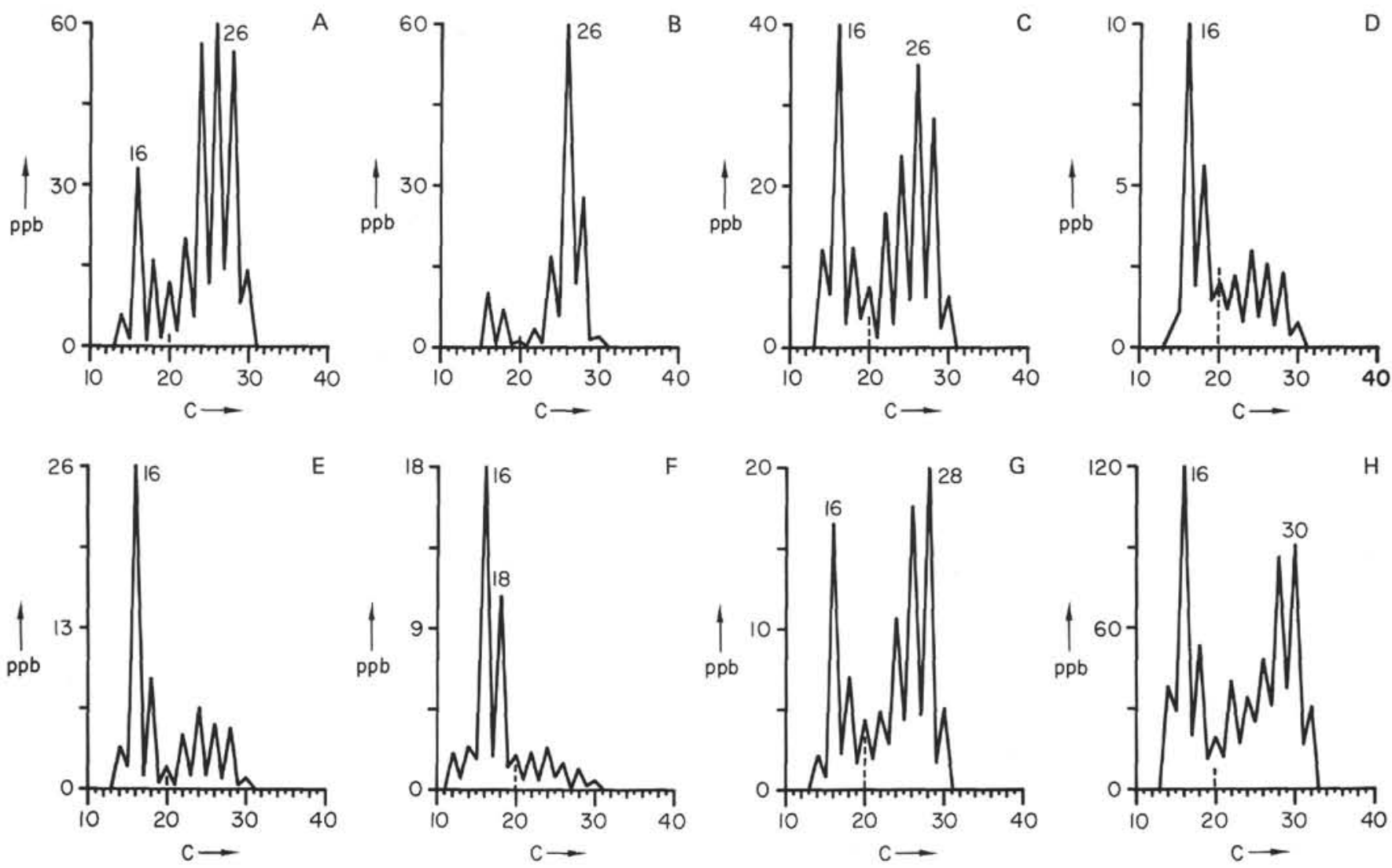

Figure 2. Distribution diagrams for the $\mathrm{n}$-fatty acids (--_- diterpenoid acid, height of line indicates approximate relative amount): (A) 391B-1-2, 6-13 cm; (B) 391A-3-4, 32-40 cm; (C) 391A-11-0, 33-41 cm; (D) 391A-21-4, 130-138 cm; (E) $391 C-7-2,142-150 \mathrm{~cm} ;(F) 391 C-14-3,142-150 \mathrm{~cm} ;$ ( G) 391C-21-3, 138-146 cm; (H) 391C-52-2, 3-10 cm.

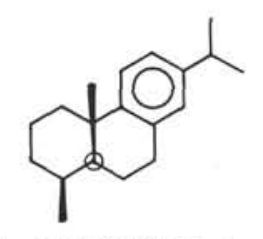

I. I. dehydroabietin, $\mathrm{G}_{19} \mathrm{H}_{28}$

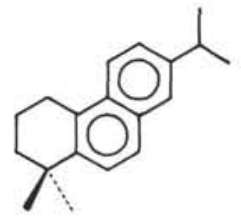

II. simonellite, $\mathrm{C}_{19} \mathrm{H}_{24}$

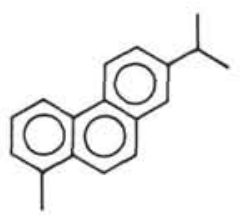

III. retene, $\mathrm{C}_{18} \mathrm{H}_{18}$
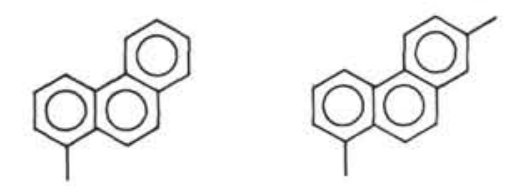

IV. 1-methyiphenanthrene, $\mathrm{C}_{15} \mathrm{H}_{12}$

V. pimanthrene, $\mathrm{C}_{16} \mathrm{H}_{14}$
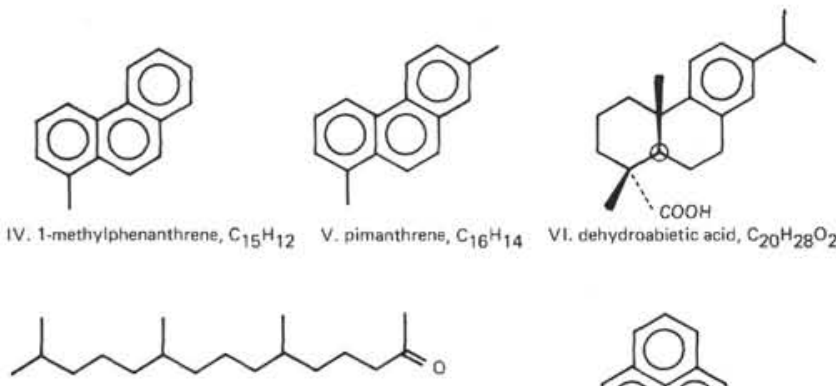

VII, 6, 10, 14-trimethylpentadecan-2-one, $\mathrm{C}_{18} \mathrm{H}_{36} \mathrm{O}$

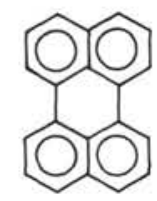

IX. perylene, $\mathrm{C}_{20} \mathrm{H}_{12}$

Figure 3. Chemical structures.

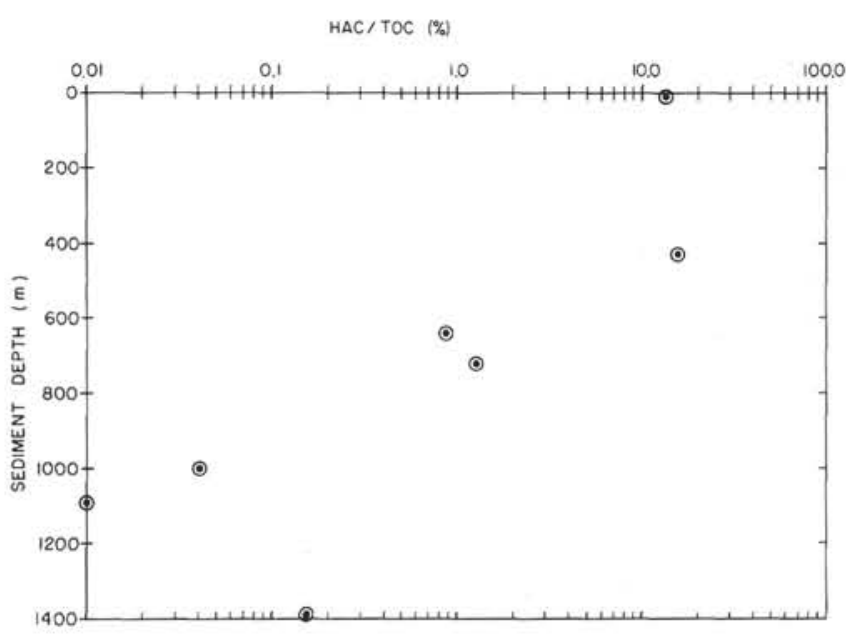

Figure 4. Plot of per cent humic acid carbon with respect to total organic carbon versus sediment depth at Site 391.

terrestrial origin while values of $-20 \%$ to $-23 \% \%$ indicate marine origin of the carbon (Nissenbaum and Kaplan, 1972; Steurmer and Harvey, 1974). Therefore, it appears that the humic substances are of autochthonous marine origin in the Quaternary hemipelagic muds and in the Miocene sediments which were displaced from shallow water and in the Quaternary hemipelagic. The humic substances deposited in the 


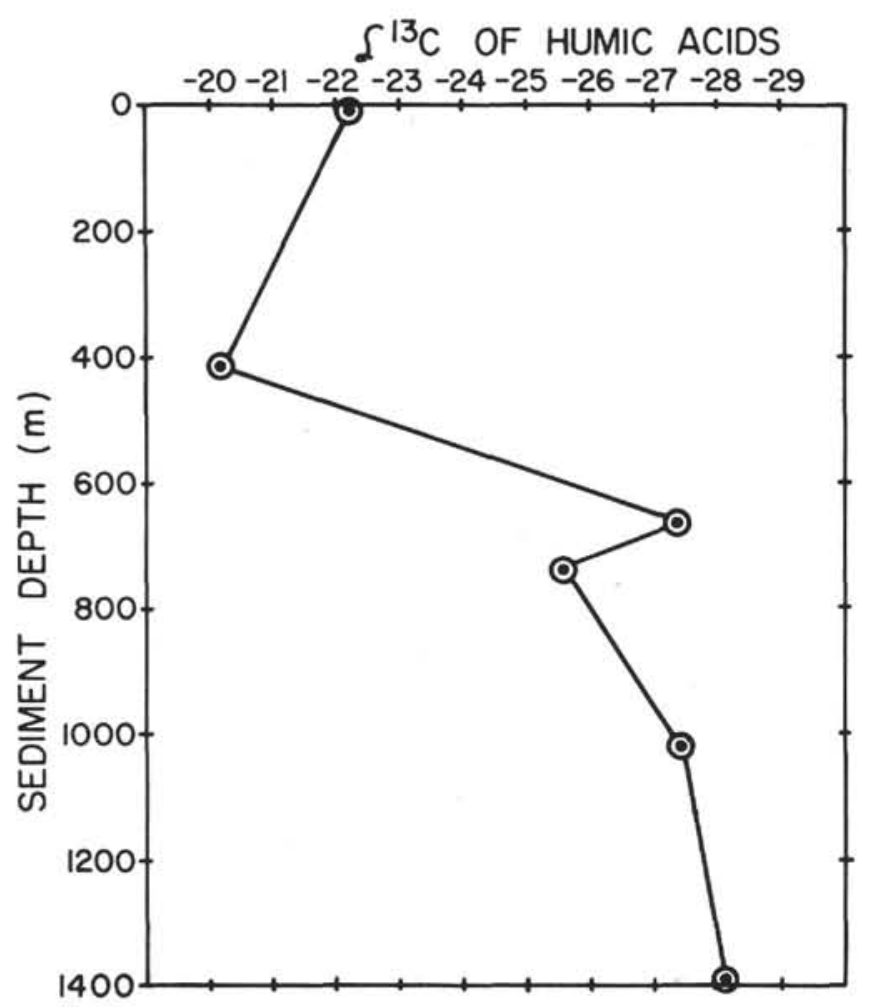

Figure 5. Plot of $\delta^{13} C$ of humic acid versus sediment depth at Site 391.

\section{CONCLUSIONS}

The lipids in the core sections examined are mainly of marine origin with some partially degraded. Minor amounts of terrestrial lipids are present. Stable carbon isotope ratios indicate that humic substances in the Quaternary and Miocene sediments are of marine origin, whereas those in the Cretaceous and Jurassic sediments are mainly terrigenous. These results suggest that during transport of terrestrial organic matter to the deep sea, the lipids are rapidly biodegraded relative to the more refractory humic substances.

The lipid distribution determined for Sample 391C-7-2, $142-150 \mathrm{~cm}$ (Albian) is similar to that of Cretaceous black shales from the eastern and southern Atlantic Ocean (Simoneit, 1977b). The predominance of phytane over pristane indicates that reducing conditions existed at the time of deposition. By contrast, however, much lower concentration of lipids are found.

A 100-fold decrease in the ratio of humic acid carbon to total organic carbon is observed with depth which may indicate that humic acid has been transformed into kerogen in this sedimentary section.

\section{ACKNOWLEDGMENTS}

The authors thank the National Science Foundation (Grant OCE 76-21506) and the National Aeronautics and Space Administration (Grant NGR 05-007-221) for support of this work. We gratefully acknowledge D. Winter for the stable isotope analyses, R.P. Philip and S.C. Brown for GC/MS data and the crew and technical staff on board Glomar Challenger for collection of core samples. We are indebted to Dr.Walter E. Reed and Dr. I.R. Kaplan for their constructive criticism of the manuscript.

\section{REFERENCES}

Bordovsky, O.K., 1965. Accumulation of organic matter in bottom sediments: Mar. Geol., v.3, p.33-82.

Degens, E.T., Reuter, J.H., and Shaw, K.N.F., 1964. Biochemical compounds in offshore California sediments and seawaters: Geochim. Cosmochim. Acta, v.38, p.45-66.

Didyk, B.M., Simoneit, B.R.T., and Eglinton, G., in press. Geochemical indicators of paleoenvironmental conditions of sedimentation: Nature.

Ishiwatari, R., Ishiwatari, M.,Rohrback, B.G., and Kaplan, I.R., in press. Thermal alteration experiments on organic matter from recent marine sediments in relation to petroleum genesis: Geochim. Cosmochim. Acta.

Kaplan, I.R., Smith, J.W., and Ruth, E., 1970. Carbon and sulfur concentration and isotopic composition in Apollo 11 lunar samples. In Proc. Apollo 11 Lun. Sci. Conf., Geochim. Cosmochim. Acta Suppl. 1, v.2: New York (Pergamon), p. 1317-1329.

Lee. R.F. and Loeblich, A.R., III, 1971. Distribution of 21:6 hydrocarbon and its relationship to $22: 6$ fatty acid in algae: Phytochem., v. 10, p.593-602.

Nissenbaum, A. and Kaplan, I.R., 1972. Chemical and isotopic evidence for the in situ origin of marine humic substances: Limnol. Oceanogr., v. 17, p.570-582.

Rashid, M.A. and King, L.H., 1971. Chemical characterization of fractionated humic acids associated with marine sediments: Chem. Geol., v. 7, p. 37-43.

Simoneit, B.R.T., 1975. Sources of organic matter in oceanic sediments: Ph.D. Thesis, University of Bristol, England. , 1977a. Search for terrigenous lipids in carbonate-rich samples from site 39-354. In Perch-Nielsen, K., Supko, P.R., et al., Initial Reports of the Deep Sea Drilling Project, v.39: Washington (U.S. Government Printing Office). , 1977b. Lipic analyses of sediments from site 40-364 in the Angola Basin. In Bolli, H.M., Ryan. W.B.F., et al., Initial Reports of the Deep Sea Drilling Project, v. 40: Washington (U.S. Government Printing Office). , in press. The Black Sea, a sink for terrigenous lipids: Deep-Sea Res.

Stuermer, D.H., and Harvey, G.R., 1974. Humic substances from seawater: Nature, v. 250 , p. $480-481$.

Wakesman, S.A., 1933. On the distribution of organic matter in the sea bottom and the chemical nature and origin of marine humus: Soil Sci., v. 36, p. 125-147. 